\title{
Bio-oil Product from Wild Brown Macro-algae Dunggan- dunggan (Padinasp) in Asturias and Carmen, Cebu, Philippines
}

\author{
Adriano R. Melendres Jr., MSc ${ }^{1}$, Anthony S. Ilano, Ph.D. ${ }^{2}$ \\ ${ }^{1}$ Cebu Technological University \\ ${ }^{2}$ University of San Carlos
}

*Corresponding Author: Adriano R. Melendres Jr, Cebu Technological University

\begin{abstract}
Present study conducted the preliminary run extracting the bio-oil in Padina sp. using conventional technique. The processing of bio-oil was conducted in Cebu Technological University - Carmen campus on August 9 to 15, 2017. Results showed that the weights in gram of bio-oil obtained per replicates; $9.93 g$
\end{abstract}

for $25 \mathrm{~g}, 21.30 \mathrm{~g}$ for $50 \mathrm{~g}$, and 32.30 for $75 \mathrm{~g}$.Overall percent yield was $41.80 \%$ for the total biomass, $450 \mathrm{~g}$. Further studies needed to verify the bio-oil in the samples for future bio-diesel production.

Keywords: Bio-oil, Biomass, Extraction technique,Macro-algae,Pyrolysis

\section{INTRODUCTION}

Seaweeds are the macro-benthic forms of marine algae that are commonly attached to the substrate. They are among the large primary producers in the shallow areas in the seas and oceans. Many of the rocky beaches, mudflats, estuaries, coral reefs and lagoons along the Philippines coast provide ideal habitats for the growth of seaweeds (Rao \&Mantri 2006). Seaweeds contain several physiologically bioactive compounds with important economical relevance including polysaccharides, iodine organic products, macro- and micro-elements, vitamins, and unsaturated fatty acids (Kim, 2011). Brown seaweeds, the second-most abundant group of marine algae, include approximately 2000 species. Among them, Sargassum spp., Laminaria spp., Ascophyllum spp., Fucus spp., and Turbinaria spp. are most commonly used at the industrial level (Wajahatullah et al., 2009). Selection of fast-growing, productive strains, optimized for the local climatic conditions is of fundamental importance to the success of any algal mass culture and particularly for low-value products for bio-oil production. Fast growth in Padina species in favored season is a good candidate for bio-oil. During photosynthesis, using only light and nutrients, algae produce lipids, proteins, and carbohydrates (Demirbas and Demirbas, 2011). Macronutrients include nitrogen, phosphorus, sulfur, potassium and magnesium. Cell's macromolecular composition determines its usefulness in biofuels production. Algae were promising organisms for providing both novel biologically active substances and essential compounds for human nutrition (Mayer and Hamann, 2004). Therefore, an increasing supply for algal extracts, fractions or pure compounds for the economical sector was needed.

Algae as renewable alternatives to fossil fuels have raised great interest as alternative means to support the demand for fossil fuel. Renewable energy is a promising alternative solution because it is clean and environmentally safe (Demirbas and Demirbas, 2011). In recent years, there has been considerable interest in producing biofuel from algae, a so-called third generation biofuel. Macroalgae (seaweeds) have a huge potential to be used as a source for the production of biofuels due to their high photosynthetic efficiency, fast growth rate, high carbohydrate content, no requirement of cultivation land area and no competition with food crops (Choia et. al., 2014). Further, macro-algae have not used as healthy food, while in Japan and China the macro-algae are traditionally used in folk medicine and as a healthy food in addition to, biofuel production. Aquatic biomass could also be used as raw material for co-firing to produce electricity, for liquid fuel (bio-oil) production via pyrolysis, or for bio-methane generation through fermentation. Bio-methane can be produced from marine biomass (Demirbas and Demirbas, 2011). Furthermore, Padina species in northern Cebu, Philippines is 
Bio-oil Product from Wild Brown Macro-algae Dunggan-dunggan (Padinasp) in Asturias and Carmen, Cebu, Philippines

abundant through its seasonal variation. Hence, among the brown macro-algae, Padina species was least tested for its oil extract. A selection of good macro-algal strain such as Padina to be used for bio-oil was important to proceed for massive extraction and utilization. Therefore, the prime investigation of this study was the feasibility of bio-oil product from brown algae Padina sp., through simplified technique of extraction.

\section{LITERATURE REVIEW}

\subsection{Macro-algae}

Marine macro-algae contribute significantly to global primary production and play critical roles in the stability and function of marine ecosystems (Inderjit et al. 2006, Williams, 2007). However, macroalgae can also become invasive in a newly introduced environment and have profound adverse ecological impacts including the alteration of ecosystem structure, reduction of indigenous biodiversity, and economic losses (Smith et al., 2010). Like plants, many algal species have rigid cellulose-based cell walls and accumulate starch as their main carbohydrate storage compounds and cell wall structure, which contains an astonishingly diverse range of simple and complex carbohydrates (Goh and Lee, 2010). Some of marine algal species like green algae contain up to 70\% of polysaccharides, i.e., cell wall polysaccharides (cellulose, hemicelluloses, xylan, and mannan), intercellular polysaccharides (sulfated glucuronoxylorhamnan, algine, agar, and carrageenin), and storage polysaccharides (amino pectin, laminaran and floridean starch). Both intercellular and cell wall polysaccharides can be converted into fermentable sugars. The majority of algal polysaccharides are potential biochemical feedstock and can be fermented to produce ethanol. Additionally, algal feedstocks have several advantages over other types of feedstocks. These include high area productivity, no competition with conventional agriculture for land, utilization of different water sources (e.g., seawater, blackish water, saline water, and wastewater), recycling of carbon dioxide, and compatibility with integrated production of fuels and co-products within biorefineries. Hence, algal feedstocks are considered one of the most promising non-food feedstocks for biofuels (Wijffels and Barbosa, 2010). Previous studies of algal biofuel production have largely focused on microalgae (Mata et al., 2010). Mannitol extracted from the brown seaweed Laminaria hyperborean has been used as a substrate for ethanol production by Zymobacterpalmaewith a yield of $0.38 \mathrm{~g}$ ethanol per gram mannital (Horn et al., 2000). A conceivable biorefinery production process of third generation ethanol using the seaweeds Euchema spp. has been proposed (Goh and Lee, 2010). However, detailed studies of macroalgal feedstock hydrolysis for ethanol fermentation are rare. Particularly, production of third generation biofuel from invasive macroaglae has not been reported.

\subsection{Advantages of Bio-oil from Macro-algae}

Renewable energy was a promising alternative solution because it is clean and environmentally safe. They also produce lower or negligible levels of greenhouse gases and other pollutants when compared with the fossil energy sources they replace (Demirbas and Demirbas, 2011). Algae are among the fastest-growing plants in the world, and about $50 \%$ of their weight is oil. That lipid oil can be used to make biodiesel for cars, trucks, and airplanes. Algae will someday be competitive as a source for biofuel. Only renewable biodiesel can potentially completely displace liquid fuels derived from petroleum. Macro-algae bio-oil can be converted to biofuels through biological and thermochemical routes (such as using organic solvents). It is reported that the maximum yield of bio-oil depends on several parameters such as water and ash contents, biomass composition, pyrolysis temperature and vapor residence time (Fahmi et al., 2008).

\subsection{Extraction Methods}

A study performed by Suh et al., 2014 detailed the quantification and determination of the by-product bio-oil through pyrolysis. Pyrolysis was carried out in a cylindrical fixed-bed reactor $(33 \mathrm{~cm}$ in length and $2.5 \mathrm{~cm}$ in diameter) filled with a screen mesh holder containing biomass particles. Nitrogen carrier gas was fed at a flow of $0.6 \mathrm{~L} / \mathrm{min}$ for $10 \mathrm{~min}$ to remove air in the reactor before reaction. The pyrolysis vapor leaving the reactor was condensed in three condensers in series (room temperature, ice water and liquid nitrogen cooled). The condensed liquid (bio-oil) was collected in flask while the solid residue (bio-char) remained in the reactor.

Pyrolysis conditions were as follows: temperature, $450{ }^{\circ} \mathrm{C}$; holding time, 8 min.; Carrier gas flow rate, $0.6 \mathrm{~L} / \mathrm{min}(2.0 \mathrm{~cm} / \mathrm{sec})$. The bio-char yield, defined as (solid dry weight) $\times 100 /$ (feed dry weight), was obtained by weighing the biomass holder before and after pyrolysis while the liquid yield was 
defined as (dry weight of collected liquids) $\times 100 /$ (feed dry weight). The gas yield was calculated from the balance. The produced bio-oil was being distilled using a vacuum distillation apparatus. $1 \mathrm{~L}$ of the crude bio-oil was put in a round bottom flask with two necks; one neck for distillation temperature measurement and control and the other neck for connecting the distillation column with 10-theoretical plates. The temperature was monitored at the top of the distillation column while the system pressure was maintained by vacuum pump (N840 Diaphragm Pump, KNF, Germany).

Hydrothermal liquefaction (HTL) is a low temperature high pressure process and biomass is converted to liquid hydrocarbon fuel (bio-oil) in the presence of a catalyst with hydrogen (Demirbas, 2001, McKendry, 2002). In practiced it would appear that the terms liquefaction, hydro-liquefaction and hydro-thermal liquefaction are synonymously used for processes where wet biomass is converted to bio-oil by temperature and pressure in the presence of a catalyst, with and without the presence of gaseous hydrogen. Hydrothermal liquefaction can be considered as pressurized aqueous pyrolysis (Marcillaet al., 2013), but produces bio-oil that is lower in oxygen and moisture content (therefore a more stable product) than from pyrolysis (Neveuxet al., 2013). Reviews of thermal treatments for biofuel production have concluded that commercial interest in liquefaction is low due to the more complex feed systems and higher costs compared with those for pyrolysis and gasification (Demirbas, 2001, McKendry, 2002); but hydrothermal upgrading of algae is attracting much interest and has the advantage of the conversion taking place in a water-containing environment and drying of biomass after harvesting may not be required prior to hydrothermal liquefaction (Minowaet al., 1995).

\section{MATERIALS AND MethodS}

\subsection{Study Site}

The processing of the study was conducted inCebu Technological University - Carmen campus. It was located in Poblacion, Carmen, Cebu. It has sufficient supply of running freshwater, seawater, and the materials including the Padinaspecies that was used in the present study.

\subsection{Collection Area and Sampling Preparation}

The collection of the samples were done from August 9 to August 15, 2017. Algal plants of genus Padina were collected in tidal flat of Asturias, and Carmen, Cebu - both of the southern part of Cebu province. Specimens were transferred to polyethylene net bag and transported directly to Aquaculture building of CTU-Carmen for drying and homogenization process. Latex gloves was worn during the cleaning process to avoid from contaminants. At least $4 \mathrm{kgs}$. Of Padina sp. wet feedstock was collected from the tidal flat of the site. After cleaning the blades and thallus of the Padina, the samples were all sundried for 4 days (Li et al., 2011) and kept for 1 day prior to its homogenization process and extraction of bio-oil. Seaweeds were soaked overnight for 2 days with the replacement of tap water in order to remove dried salts and organic debris in the seaweed (Fakhrudin et al., 2014). All dried blades and thalli of Padina species were weighed usingdigital analytical balance by batch $\left(1^{\text {st }}\right.$ batch $-250 \mathrm{~g}, 2^{\text {nd }}$ batch $-500 \mathrm{~g}$, and $3^{\text {rd }}$ batch $750 \mathrm{~g}$ ). During the homogenization process, Padina sp. were mixed with distilled water $(2 \mathrm{~g}: 1 \mathrm{ml})$ and soaked for 30 minutes in aluminum pan.

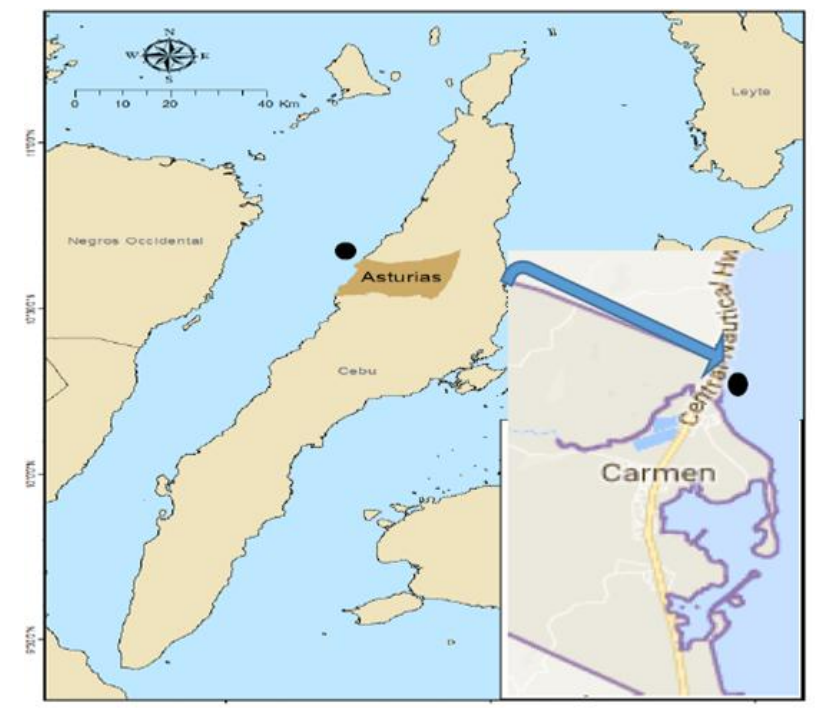

Figure1. Source of brown algae (Padina species) in Cebu province 


\subsection{Bio-oil Separation and Yield Composition}

The sundried seaweed samples of the Padina sp. were placed in a commercial juicer/blender for 5 minutes and monitoring the rotation of the extractor and of the samples by executing on/off technique along the process. After blending, the homogenates were transferred in a 1L Erlenmeyer flask. Hexane and ether solution (20:20 mL) wasadded and mixedinto the dried ground seaweedsfor time intervals with their exact weights such as; 6:00 PM for 250g, 6:30 PM for 500g, and 7:00 PM for $750 \mathrm{~g}$ for which to extract the bio-oil. Extraction time were recorded and done for every treatment interval. Then all the replicates of the mixtureswere kept for $24 \mathrm{~h}$ for settling (Hossain et al., 2008). The solid residue remained in the aluminum cups were buried after the extraction process. Separation of the oil from the homogenatesthrough filtration using filter membrane and were weighed using digital analytical balance after 24 hours and directly stocked in a 6 pcs of aluminum cups $(100 \mathrm{ml}$ capacity) covered with aluminum foil for 3 to 4days. Observation of color, the decrease of the $\mathrm{ml}$ concentration and odor change of the bio-oil were noted and recorded.

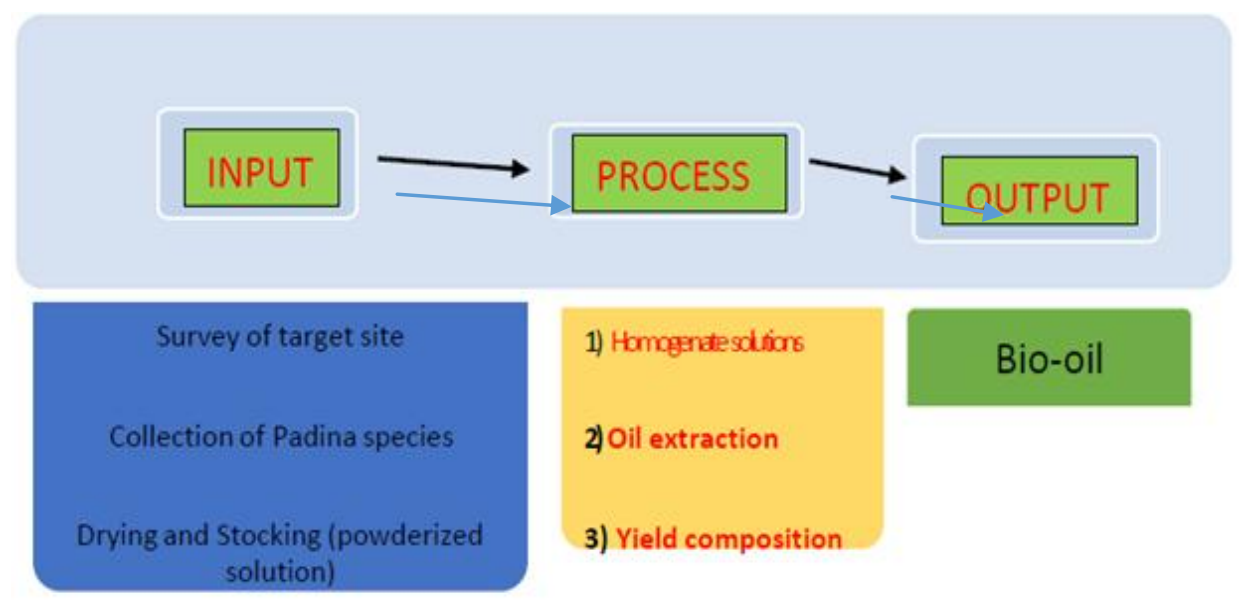

Fig2. Overall procedures of Bio-oil extract using known weights of brown macroalgae Padina species

Same procedures were repeated for the remaining grounded seaweedse.g., $500 \mathrm{~g}$ with 40 and $40 \mathrm{ml}$ solution and increase to 60 and $60 \mathrm{ml}$ for $750 \mathrm{~g}$ leaf blades of Padina to analyze the percent yield product. A formula being used for percent yield composition was:

$\mathbf{Y}_{\text {bio-oil }} \%=W_{\text {bio-oil }} / W_{\text {feedstock }} \times 100$ (Li et al., 2011)

\subsection{Statistical Analysis}

In descriptive form, bio-oil yield products using its mean values per gram of sample were compared for each treatment using tabular form considering the factors and the effects of 'treatment' and 'time' (random factor) during the manipulative approach were evaluated. Further, getting the means of biooil extract per treatment used were presented for comparison of its strength base on color and odor and precipitate formation. The comparisons of bio-oil yield were all extrapolated using MINITAB ver. 17, and individual value plot were presented per gram treatment of the sample with their corresponding gram concentration of bio-oil formed according to time fraction.

\section{RESULTS AND DISCUSSION}

\subsection{Bio-oil Extracts and Yield Composition}

The bio-oil extraction capabilities of petroleum ether and hexane were shown in Figure 2. The mean grams of bio-oil recovered from Padina sp. was calculated as shown in Figure 6 with 39.73\% yield for $250 \mathrm{~g}$ of Padina feed stock, followed by $42.60 \%$ of $500 \mathrm{~g}$ feedstock and $43.07 \%$ for $750 \mathrm{~g}$ feedstock. Total extraction of bio-oil obtained was 190.60g (see Fig. 3 \& Fig. 4) whereas the cumulative value of $450 \mathrm{~g}$ if for all weights of the Padina samples used in the study were added. Figure 3 shows the scatterplot relationship of the weights in gram of bio-oil obtained per replicates showing the mean value of $9.93 \mathrm{~g}$ for $25 \mathrm{~g}, 21.30 \mathrm{~g}$ for $50 \mathrm{~g}$, and 32.30 for $75 \mathrm{~g}$. The mechanical 
Bio-oil Product from Wild Brown Macro-algae Dunggan-dunggan (Padinasp) in Asturias and Carmen, Cebu, Philippines

technique of extracting the bio-oil from the sample brown algae with hexane and petroleum ether solvents was easy but the selection of the appropriate method varies according to the nature of the target compound to get maximum yield and highest purity (Wang et al., 2006). Two solvents were used to evaluate their efficiency for the quantity of the by-product. Table 1 shows the comparative data of oil extracted by use of solvents (hexane and ether solution) and conventional extraction method (maceration technique). The best result was obtained for highest weights in gram of Padina sample which was $75 \mathrm{~g}$, otherwise it also directly correlates of the direct effect of the grams used for the bio-oil output. Higher amount of feedstock will yield more oil than lesser amounts of weights of feedstock as reflected in Figures $4 \& 5$. Use of maceration technique with the aqueous solution hexane and ether petroleum for oil extraction, was found to yield the overall $41.80 \%$ of bio-oil (Figure 5). Studies by authors Gupta et al., 2005 the data obtained with different solvents used, yielded in the range of 17 to $21 \%$ as reported. And conversely the enzymes used such as cellulase and pectinase failed to extract large amount of bio-oil. Brown macro-algae contain alginate, mannitol and laminarin as their major carbohydrates. (Yanagisawa et al., 2013) Marine macro-algae (green, red and brown macro-algae) have attracted attention as an alternative source of renewable biomass for producing both fuels and chemicals due to their high content of suitable carbohydrates and to their advantages over terrestrial biomass.

Algae oil can be extracted through a wide variety of methods but in the present study, researcher have used simple procedure to extract bio-oil from the sample species of brown algae. When algae are dried, it retains its oil content, which then can be pressed out when catalyst such as hexane and ether petroleum must be added.The processes together were able to derive $87 \mathrm{ml}$ of bio-oil, if the technology for extracting the Padina species would be used instead of manual pressing by hands, maybe the $\mathrm{ml}$ concentration of extracted bio-oil would increase. Algae oil can be converted to biodiesel by using a trans-esterification process according to Milledge et al., 2014.The biodiesel product has its main characteristics quite similar to those of conventional diesel or compatible with conventional petroleum diesel, and it can also be blended in any proportion with petroleum diesel.

Table1. Descriptive statistics of bio-oil yield from the Padina species

\begin{tabular}{|c|c|c|c|c|c|c|c|c|c|c|c|}
\hline Variables & $\begin{array}{c}\text { Settlin } \\
\mathbf{g} \\
\text { Time } \\
\text { (h) }\end{array}$ & $\begin{array}{c}\text { Total } \\
\text { Coun } \\
\mathbf{t}\end{array}$ & $\begin{array}{c}\text { Cum } \\
\boldsymbol{\%}\end{array}$ & $\begin{array}{c}\text { Mea } \\
\mathbf{n}\end{array}$ & $\begin{array}{c}\text { S.E. } \\
\text { Mean }\end{array}$ & $\begin{array}{c}\text { St. } \\
\text { Dev }\end{array}$ & $\begin{array}{c}\text { Sum of } \\
\text { Squares }\end{array}$ & Q1 & Med. & $\begin{array}{c}\text { Q3 } \\
\text { Rang } \\
\text { e }\end{array}$ & \\
\hline $\begin{array}{c}\text { Padina wt. } \\
\text { (g) }\end{array}$ & 24 & 9 & 100 & 50 & 7.22 & 21.65 & $\begin{array}{c}26250.0 \\
0\end{array}$ & 25 & 50 & 75 & 50 \\
\hline \begin{tabular}{c} 
Bio-oil wt. (g) \\
\hline
\end{tabular} & 24 & 9 & 100 & 21.18 & 3.33 & 9.98 & 4832.88 & 10.5 & $\begin{array}{c}21.6 \\
0\end{array}$ & $\begin{array}{c}31.0 \\
5\end{array}$ & 26.00 \\
\hline
\end{tabular}

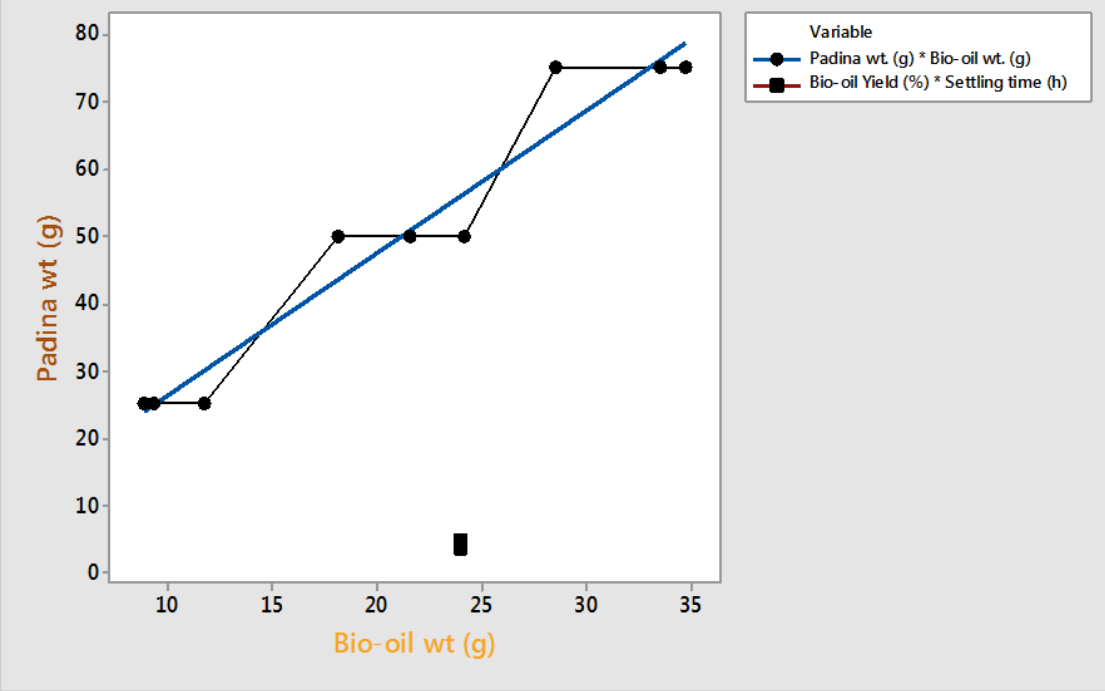

Figure3. Scatterplot of the bio-oil ( $g$ ) obtained from the feedstock $(g)$ of Padina sp 
Bio-oil Product from Wild Brown Macro-algae Dunggan-dunggan (Padinasp) in Asturias and Carmen, Cebu, Philippines

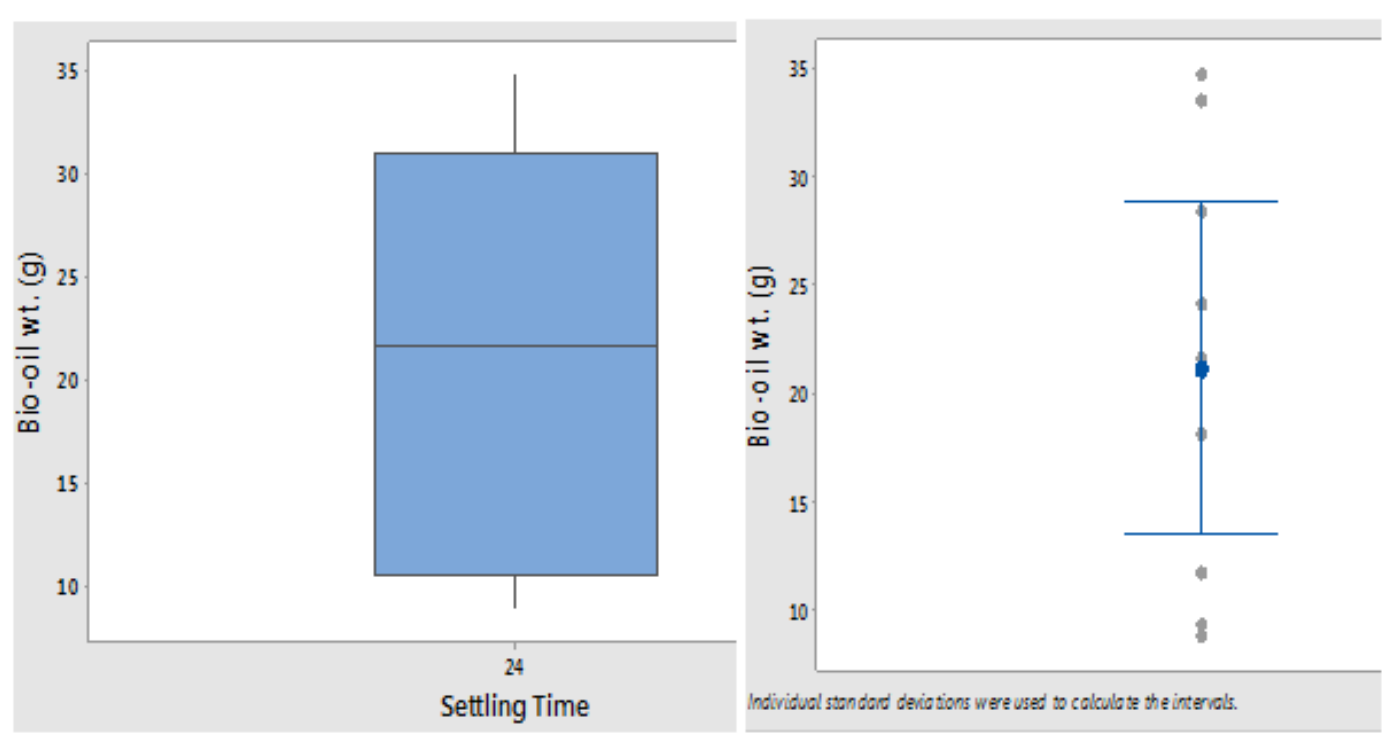

Figure4. Boxplot of bio-oil ( $g$ ) obtained from the Padina species according to its 24 hours settlingtime and for $95 \%$ CI of mean $(21.18 \mathrm{~g})$

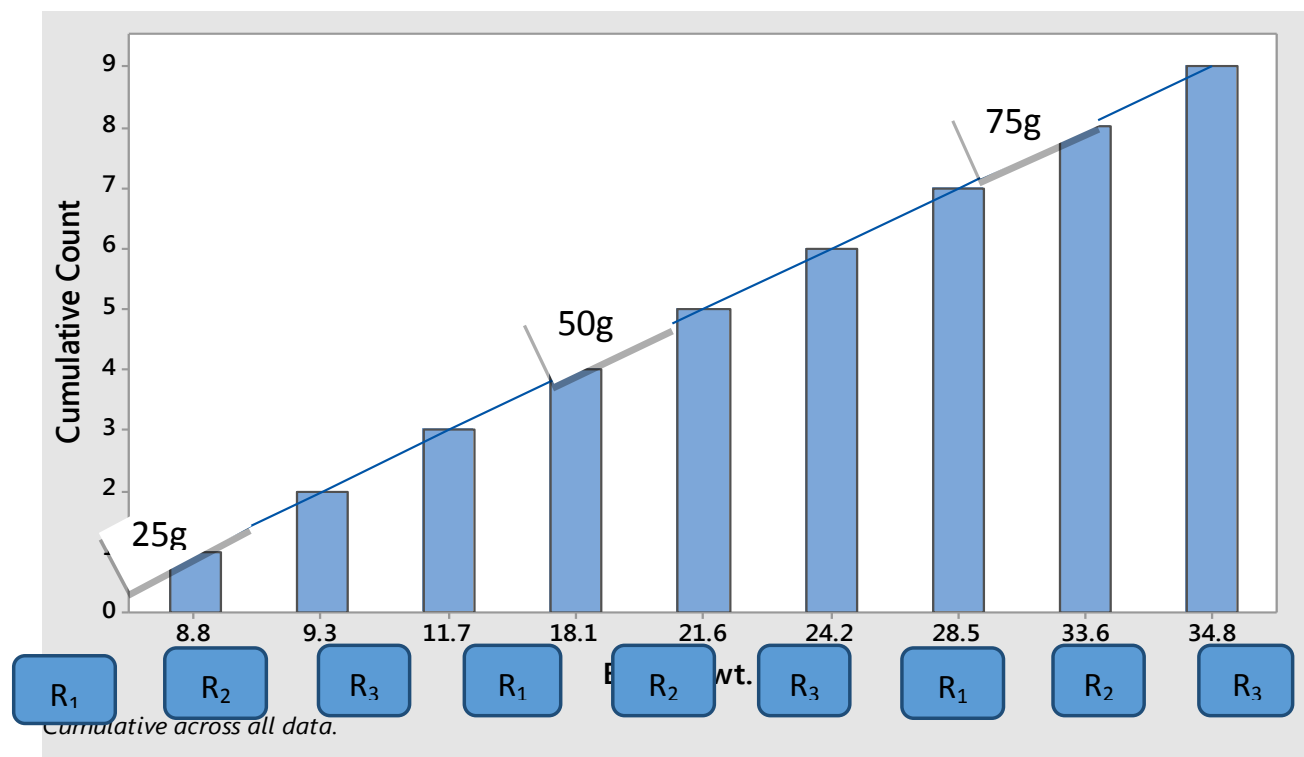

Figure5. Cumulative counts of bio-oil ( $g$ ) gained from different replicates of 25, 50, and 75gPadina sp. with $41.80 \%$ mean bio-oil yield

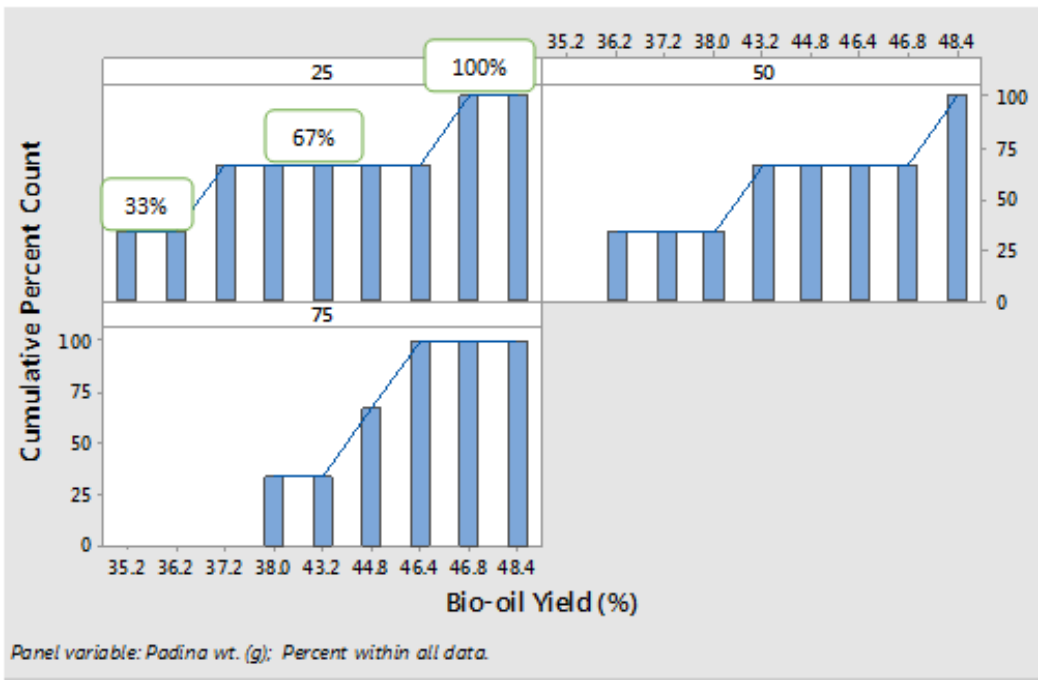

Figure6. Chart of bio-oil yield (\%) from the different Padina species feedstock 


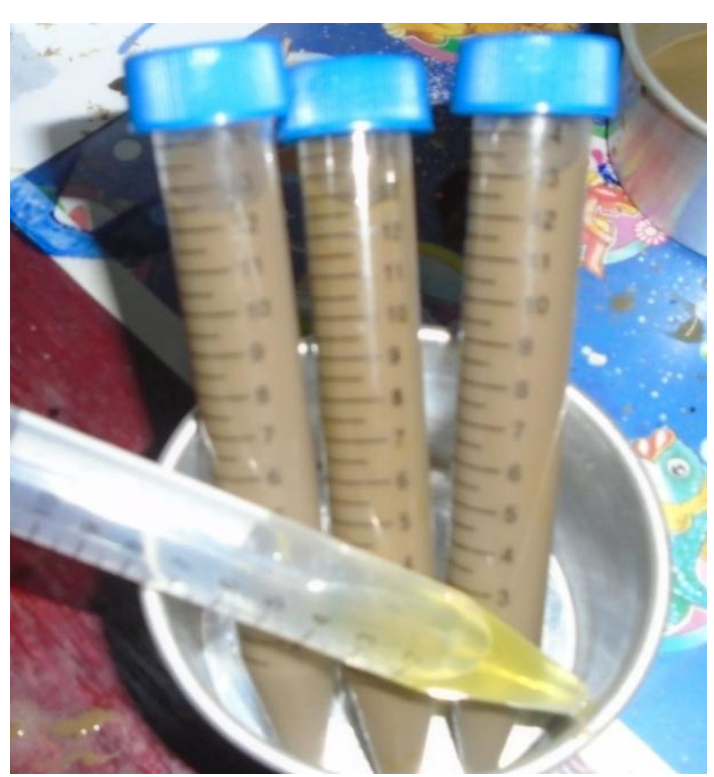

Figure7. Color of the bio-oil and unseparated after 24 hours

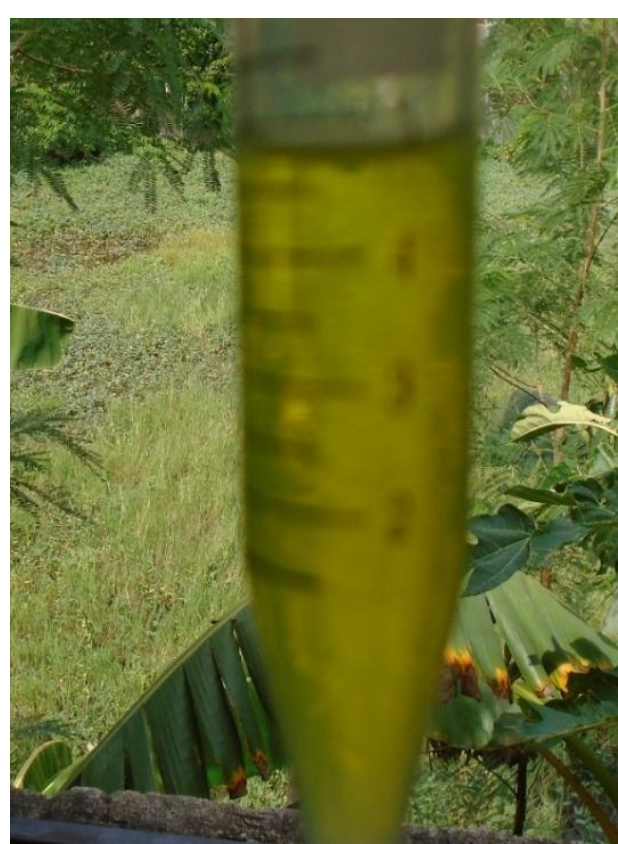

Figure8. Bio-oil from Padina sp. after 72 hours

of observation

\subsection{Physico-chemical Property of Oil}

The physical property that is, color and odor of the oil extracted by solvent used in the extraction process was also studied. All bio-oil yields indistinct yellow with more of black impurities. Bio-oils are usually dark brown, free-flowing liquids having a distinctive smoky odor. The physical properties of bio-oils are described in several publications (Akhtar and Amin, 2011, Lu et al., 2009). The different physical properties of bio-oils result from the chemical composition of the oils, which is significantly different from that of petroleum derived oils. Bio-oil is a complex mixture of several hundreds of organic compounds, mainly including acids, alcohols, aldehydes, esters, ketones, phenols, and lignin-derived oligomers. Some of these compounds are directly related to the undesirable properties of bio-oil. As separated from the first extracted product, later it changed to pale (light) yellow after 3 days of observation. The free radical scavenging activity, expressed in percentage inhibition of the leaf blade and oil extract of Padina species. The odor from strong because of the impurities both from the aqueous solution and the blades and thallus of dried Padina sp. to weaker odor of alcohol after 3 days. As it was observed, the ml concentrations of the bio-oil products were reduced to 10 to $15 \%$ after the coverage of the study for 3 to 4 days, showing that there is the free scavenging activity of the bio-oil. There were no solids formed during first two days but fewer organic debris such as silts upon the extraction and separation of the oil juice from the homogenates by filtration through using filter membrane were stocked in a 6 pcs of aluminum cups $(100 \mathrm{ml}$ capacity) after 24 hours of settling. The effect of thecatalyst,holding time and room temperature on bio-oil production was illustrated in figures 7 and 8 .

The properties of bio-oil from both processes are significantly different from heavy petroleum fuel oil. Compared with heavy petroleum fuel oil, the bio-oils have the following undesired properties for fuel applications: (1) high water content, (2) high viscosity, (3) high ash content, (4) high oxygen content (low heating value), and (5) high corrosiveness (acidity) (Xiu and Shahbazi, 2012). These undesired properties have so far limited the range of bio-oil application. Overall, bio-oils cannot be directly used as transportation fuels due to their high viscosity, high water and ash contents, low heating value, instability and high corrosiveness. Therefore, upgrading of bio-oil is needed to improve its properties for liquid fuel (Xiu and Shahbazi, 2012).

This study represents the first step toward the development of a bio-diesel and bio-fuel from the biooil of Padina species. Many algae are exceedingly rich in oil. The oil content of some microalgae exceeds $80 \%$ of the dry weight of algae biomass (Patil et al., 2007), some have about 15-40\% (dry weight), whereas palm kernel has about 50\%, copra has about60\%, sunflower has about $55 \%$. Oil 
content itself can be estimated to be $64.4 \%$ of the total lipid component by Hill, 1984. In this present study the bio-oil obtained from the extracted bio-oil of Padina sp. was differed. The mean from the total 9 replicates was $21.18 \mathrm{~g}$ for 24 hour settling period.Figure 2 shows the processes involved from obtaining the bio-oil of the present study using the good and healthy Padinablades and thalli. The results revealed that extraction through conventional method yielded bio-oil (\%) in the range of 35\% to $48 \%$ (see Figure 6). this preliminary study entails the $90 \%$ recovery of oil from the extract outputs after mixing and extracting the homogenates, because of some minor problems encountered during the separation from the impurities obtained with bio-oil on top of the extract while comparing the oil recovery after 3 days was about $75 \%$ - a lost of at least $15 \%$ since from the first day of observation. For better oil yield, additional enzyme preparation such as Protizyme, Pectinex Ultra SP-L, Promozyme, etc. are required (Gupta et al., 2005). A two-step process was investigated for feedstock having the high fatty acid content (Akbar et al., 2009). Previous reports have indicated that sodium carbonate was an effective catalyst for bio-oil production from cellulose (Minowa et al., 1998). But the present study uses the biomass of the Padina sp. It increased the bio-oil yield in water and reduced the gas, bases and bicarbonates formed, which can suppress the formation of char (Xu and Lad, 2007).

Further, this is a preliminary on the status of macro-algae Padina feedstock for the possibilities as biofuel and biodiesel production in the future. some of the common genera of brown marine algae includes; Ascophyllum, Sargassum and Laminaria and Globally there are 1,500 to 2,000 species of brown algae (van den Hoek et al., 1995).Macroalgae has potential to provide various kinds of chemical products and byproducts, but nowadays it is generally used for single product such as bioethanol or alginate etc.Existing techniques used for extraction of bioactive compounds include soxhlet, pyrolysis, hydrodistillation and maceration with alcohol. To better exploit this potential, there is a need to develop new and enhanced novel extraction technologies. However, it will be necessary to take into consideration that, variations in $\mathrm{pH}$, temperature and time can make subtle changes under hydrothermal conditions both on less important products and high value added products (Jeon et al., 2015). Conventional extraction techniques are time consuming and are not eco-friendly due to the use of organic solvents. Yields obtained with traditional solvent extraction techniques are also limited compared to the novel extraction technologies outlined in this paper which have the potential to significantly improve extraction efficiency. But hydrothermal liquefaction (HTL) of brown seaweed on the other end, was estimated to produce bio-oil yields of $23 \mathrm{~kg} / 100 \mathrm{~kg}$ dry seaweed for light crude and $10 \mathrm{~kg} / 100 \mathrm{~kg}$ dry seaweed for heavy crude (Reith et al., 2009).This estimation is closer to bio-oil production from the present study using brown seaweed, Padina sp. Depending upon the conversion methods, either wet or dry macro-algae can be used. Anaerobicfermentation or liquefaction can directly use wet feedstock (Chynoweth et al., 2001; Aresta et al., 2005).

\section{CONCLUSION}

The extraction of bio-oil from brown macro-algae (Padina species) gave comparable percentage of bio-oil yields of $41.80 \%$. The mean weights in gram obtained per replicates were; of $9.93 \mathrm{~g}$ for $25 \mathrm{~g}$, $21.30 \mathrm{~g}$ for $50 \mathrm{~g}$, and 32.30 for $75 \mathrm{~g}$. Petroleum Ether and Hexane were the solution used in the study to obtain the other extraction methods. Light yellow from pale yellow as first observed from the extracts with brown to black residues were observed after 3 days of observation. Strong odor were also sensed prior to the maceration process until the end of the study. The mean bio-oil weights from the total 9 replicates was $21.18 \mathrm{~g}$ for 24 hour settling period. This study is a preliminary on the status of macroalgae Padina feedstock for the possibilities as biofuel and biodiesel production in the future. Further studies using newer technique of extraction with novel technologies was suggested to enhance the bio-oil presence in Padina species.

\section{REFERENCES}

Akbar, E., Yakoob, Z., Kamarudin, S.K., Ismail, M., and Salimon, J. 2009. Characteristic and composition of Jatrophacurcas oil seed from Malaysia and its potential as biodiesel feedstock. EurJourn Science Research. 29(3): 396-403.

Akhtar, J, and N.A.S. Amin. 2011. A review on process conditions for optimum bio-oil yield in hydrothermal liquefaction of biomass. Renewable and Sustainable Energy Reviews. 15:1615-24.

Anastasakis, K. and A.B. Ross. 2011. Hydrothermal liquefaction of the brown macroalga Laminaria Saccharina: effect of reaction conditions on product distribution and composition. Bioresources Technology. 102: 4876-4883. 
Bio-oil Product from Wild Brown Macro-algae Dunggan-dunggan (Padinasp) in Asturias and Carmen, Cebu, Philippines

Aresta, M., Dibenedetto, A., Carone, M., Colonna, T. and C. Fragale. 2005. Production of biodiesel from macroalgae by supercritical $\mathrm{CO} 2$ extraction and thermochemical liquefaction. Environmental Chemistry Letters. 3: 136-139.

Bastianoni, S., Coppola, F., Tiezzi, E., Colacevich, A., Borghini, F., and S. Focardi. 2008. Biofuel potential production from the Orbetello lagoon macroalgae: A comparison with sunflower feedstock. Biomass \& Bioenergy. 32(7): 619-628.

Chynoweth, D. P., Owens, J.M., and R. Legrand. 2001. Renewable methane from anaerobic digestion of biomass. Renewable Energy 22(1-3): 1-8.

Christi Y. 2007. Biodiesel from microalgae. Biotech Advances. 25: 294-306.

Demirbas, A. 2001. Biomass resource facilities and biomass conversion processing for fuels and chemicals. Energy Conversion Management. 42, 1357-1378.

Demirbas, A. and M.F. Demirbas. 2011. Importance of algae oil as a source of biodiesel. Energy Conversion and Management. 52, 163-170.

Fakhrudin, N., Waltenberger, B., Cabaravdic, M., Atanasov, A.G., Malainer, C., Schachner, D., Heiss, E.H., Liu, R., Noha, S.M., Grzywacz,A.M., Mihaly-Bison, J., Awad, E,M., Schuster, D., Breuss, J.M., Rollinger, J.M., Bochkov, V., Stuppner, H., and Dirsch, V.M. 2014. Identification of plumericin as a potent new inhibitor of the NF- jBpathway with anti-inflammatory activity in vitro and in vivo. Br Journ of Pharmacol. 171(7):1676-86.

Fahmi R., Bridgwater A.V., Donnison I., Yates N. 2008. The effect of lignin and inorganic species in biomass on pyrolysis oil yield, quality and stability. Fuel 87, 1230-1240.

Feng, F., van der Kooi, J., and J. de SwaanArons. 2004. Biomass conversions in subcritical and supercritical water: driving force, phase equilibria, and thermodynamic analysis. Chem. Eng. Process. 43: 1459-1467.

Hill AM, and D.A. Feinberg. 1984. Fuel from microalgae lipid products. In: Presented at the energy from biomass: building on a generic technology base. Second Tech. Rev. Meeting, Portland-Oregon, $23-25$.

Hoek van den, C., Jahns, D. M., and Jahns. H.M. 1995. Algae: an introduction to phycology. Cambridge University Press: p. 640.40.

Horn, S.J.; Aasen, I.M.; Ostgaard, K. 2000. Ethanol production from seaweed extract. Journal Indian Microbiology and Biotechnology 25, 249-254.

Hossain Sharif, A.B.M, Salleh, A., Boyce, A.N., Chowdhury, P. and M. Naqiuddin. 2008. Biodiesel Fuel Production from Algae as Renewable Energy. American Journal of Biochemistry and Biotechnology 4 (3):250-254.

Goh C.S. and K. T. Lee. 2010. A visionary and conceptual macroalgae-based third-generation bioethanol (TGB) biorefinery in Sabah, Malaysia as an underlay for renewable and sustainable development. Renewable and Sustainable Energy Reviews. vol. 14, issue 2, 842-848.

Gupta MP, Solis, P.N., Calderon, A., Guionneau-Sinclair, F., Correa, M., Galdames, C., Guerra, C., Espinosa, A., Alvenda, GI, Robles, G., and Ocampo, R. 2005. Medical Ethnobotany of the Teribes of Bocas del Toro, Panama. Journal of Ethno-pharmacology 96:389-401.

Jeon, W., Ban, C., Park, G., Yu, T., Suh, J., Chul, H., and D. Heui, D. 2015. Catalytic hydrothermal conversion of macroalgae-derived alginate: effect of $\mathrm{pH}$ on production of furfural and valuable organic acids under subcritical water conditions, J. Mol. Catal. A Chem. 399: 106-113.

Kim, S.K. 2011. Handbook of Marine Biotechnology. Springer Dordrecht Heidelber London New York. ISBN: 978-3-642-53970-1; e-ISBN: 978-3-642-53971-8.

Li, L., L. Chen, D. Xu, X. Zhang, N. Ye, F. Chen, and S. Chen. 2012. Preparation and characteristics of biooil from the marine brown alga Sargassum patens C. Agardh. Bioresource Technology. 104: 737-742.

Lu Q, Li WZ, and X.F Zhu. 2009. Overview of fuel properties of biomass fast pyrolysis oils. Energy Conversion and Management. 50(5):1376-83.

Marcilla, A., Catalá, L., García-Quesada, J.C., Valdés, F.J., Hernández, M.R. 2013. A review of thermochemical conversion of microalgae. Renewable Sustainable Energy Reviews. 27: 11-19.

Mata, T.M., Martins, A.A., Caetano, N.S. 2010. Microalgae for biodiesel production and other applications: A review of Renewable Sustainable Energy Rev. 14:217-232.

Mayer, A.M. and M.T. Hamann. 2004. Marine pharmacology in 2000: Marine compounds with antibacterial, anticoagulant, antifungal, anti-inflammatory, antiplatelet, anti-tuberculosis, and antiviral activities; affecting the cardiovascular, immune, and nervous systems and other miscellaneous mechanisms of action. Marine Biotechnology. pp. 37-52.

McKendry, P. 2002. Energy production from biomass (part 2): Conversion technologies. Bioresource Technology.83: 47-54.

Milledge, J.J., Smith, B., Philip W. Dyer, D.W., and Harvey, P. 2014. Macro-algae-Derived Biofuel: A Review of Methods of Energy Extraction from Seaweed Biomass. Energies. 7: 7194-7222. 
Bio-oil Product from Wild Brown Macro-algae Dunggan-dunggan (Padinasp) in Asturias and Carmen, Cebu, Philippines

Minowa, T., Murakami, M., Dote, Y.,Ogi, T., and Yokoyama, S.Y. 1995. Oil production from garbage by thermochemical liquefaction. Biomass Bioenergy 8: 117-120.

Minowa, T., Yokoyama, S.Y., Kishimoto, M., and Okakura, T., 1995. Oil production from algal cells of Dunaliellatertiolecta by direct thermochemical liquefaction. Fuel 74: 1735-1738.

Neveux, N., Yuen, A.K.L., Jazrawi, C., Magnusson, M., Haynes, B.S., Masters, A.F., Montoya, A., Paul, N.A., Maschmeyer, T., and de Nys, R. 2014. Bio-crude yield and productivity from the hydrothermal liquefaction of marine and freshwater green macroalgae. Bioresource. Technology. 155, 334-341.

Ochiai, A., Yamasaki, M., Mikami, B., Hashimoto, W., and Murata, K. 2010. Crystal structure of exotype alginate lyase Atu3025 from Agrobacterium tumefaciens. Journal of Biology Chemistry. 285: 2451924528.

Patil, V., Tran, K.Q., and Giselrod, H.R. 2008. Toward sustainable production of biofuels from microalgae. International Journal on Molecular Sciences. 9:1188-95.

Rao P. V. S. and V.A. Mantri.2006. Indian seaweed resources and sustainableutilization scenario at the dawn of a new century. Current Science 91: 161-174

Reith, J. H., Huijgen, W., van Hal. J., and J. Lenstra. 2009. Seaweed potential in the Netherlands. Macroalgae - Bioenergy Research Forum. Plymouth, UK.

Smith, D., Lee, R., Cushman, J., Magnuson, J., Tran, D., andPolle, J. 2010.The Dunaliellasalinaorganelle genomes: Large sequences, inflated with intronic and intergenic DNA. BMC Plant Biology. 10: 83-96.

Suh D.J., Choi J.H., and Woo H.C. 2014. Pyrolysis of seaweeds for bio-oil and bio-char production, Chemical Engineering Transactions. 37, 121-126.

Wajahatullah, K., Rayirath, U.P., Subramanian, S., Jithesh, M.N., Rayorath, P., D. Mark Hodges, P.D., Critchley, A.T., Craigie, J.S., Norrie, J., and BalakrishanPrithiviraj. 2009. Seaweed Extracts as Biostimulants of Plant Growth and Development. Journal of Plant Growth Regulation, 28: 386-399.

Wang, L., and C.L. Weller. 2006. Recent advances in extraction of nutraceuticals from plants. Trends Food Science Technology.17; 300-312.

Wijffels, R.H. andM.J.Barbosa.2010. An outlook on microalgal biofuels. Science 329: 796-799.

Williams, P.J.L.B. and L.M.L. Laurens. 2010. Microalgae as biodiesel \& biomass feedstocks: Review \& analysis of the biochemistry, energetics \& economics. Energy Environmental Science 3: 554-590.

Yanagisawa, M.; Kawai, S.; and Murata, K. 2013. Strategies for the production of high concentrations of bioethanol from seaweeds: Production of high concentrations of bioethanol from seaweeds. Bioengineered. 4: 224-235.

Yang, Y.F., Feng, C.P., Inamori, Y., and Maekawa, T. 2004. Analysis of energy conversion characteristics in liquefaction of algae. Resour. Conserv. Recycl. 43: 21-33.

Xu, C. and N. Lad.2007. Production of Heavy Oils with High Caloric Values by Direct Liquefaction of Woody Biomass in Sub/Near-critical Water. Energy \& Fuels. 22(1): 635-642.

Xiu, S. and A. Shahbazi. 2012. Bio-oil production and upgrading research: A review. Renewable and Sustainable Energy Reviews. Science Direct. 16: 4406-4414.

Zhou, D., Zhang, L., Zhang, S., Fu, H., and Chen, J. 2010. Hydrothermal liquefaction of macro-algae Enteromorphaprolifera to bio-oil. Energy Fuels. 24: 4054-4061.

Citation: A. Melendres \& Anthony S. Ilano, "Bio-oil Product from Wild Brown Macro-algae Dunggandunggan (Padinasp) in Asturias and Carmen, Cebu, Philippines", International Journal of Medicinal Plants and Natural Products (IJMPNP), vol. 3, no. 2, pp. 27-36, 2017. http://dx.doi.org/10.20431/2454-7999.0302004

Copyright: (c) 2017 Authors. This is an open-access article distributed under the terms of the Creative Commons Attribution License, which permits unrestricted use, distribution, and reproduction in any medium, provided the original author and source are credited. 